Die ^Nibelungenklage`

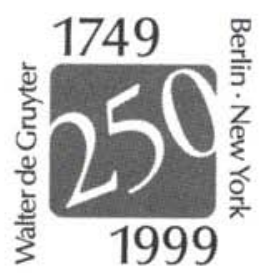





\title{
Die Nibelungenklage
}

Synoptische Ausgabe aller vier Fassungen

\author{
Herausgegeben von \\ Joachim Bumke
}

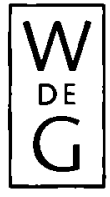

Walter de Gruyter · Berlin · New York 1999 
(0) Gedruckt auf säurefreiem Papier, das die US-ANSI-Norm über Haltbarkeit erfüllt.

\section{Die Deutsche Bibliothek - CIP-Einheitsaufnabme}

Die „Nibelungenklage“ : synoptische Ausgabe aller vier Fassungen / hrsg. von Joachim Bumke. - Berlin ; New York : de Gruyter, 1999

ISBN 3-11-016323-3

(C) Copyright 1999 by Walter de Gruyter GmbH \& Co. KG, D-10785 Berlin

Dieses Werk einschließlich aller seiner Teile ist urheberrechtich geschützt. Jede Verwertung außerhalb der engen Grenzen des Urheberrechtsgesetzes ist ohne Zustimmung des Verlages unzulässig und strafbar. Das gilt insbesondere für Vervielfältigungen, Übersetzungen, Mikroverfilmungen und die Einspeicherung und Verarbeitung in elektronischen Systemen.

Printed in Germany

Diskettenkonvertierung und Druck: Arthur Collignon GmbH, Berlin

Buchbinderische Verarbeitung: Lüderitz \& Bauer, Berlin 
Thomas Cramer gewidmet 
